\title{
The Effect of Medium on the $\alpha$-Effect: Nucleophilic Substitution Reaction of $p$-Nitrophenyl Diphenyl Phosphinate with Butane-2,3-dione Monoximate and Substituted Phenoxides in Cationic Micelles"
}

\author{
Jin-Kyung Limb, Sang-Eun Jeon, Seung-Eun Lee, and Ik-Hwan Um* \\ Department of Chemisty, Ewha Womans Unwersity; Seoul 120-750, Korea \\ Received April 9, 2002
}

\begin{abstract}
Pseudo-first-order rate constants $\left(k_{\text {ons }}\right)$ have been determined for the nucleophilic substitution reactions of $p$ nitrophenyl diphenyl phosphinate (PNPDPP) with substituted phenoxides $\left(\mathrm{XC}_{(1} \mathrm{I}_{4} \mathrm{O}\right)$ and butane-2.3-dione monoximate $(\mathrm{Ox})$ in $0.1 \mathrm{M}$ borate buffer $\left(\mathrm{pl}[-10.0)\right.$ at 25.0 । $0.1^{\circ} \mathrm{C}$. The $k_{0 \mathrm{lls}}$ value increases sharply upon addition of cethyltrimethylammonium bromide $\left(\mathrm{CT} \Lambda \mathrm{B}\right.$ ) to the reaction medium up to near $7 \times 10^{1} \mathrm{M} C \mathrm{CT} \wedge \mathrm{B}$ and then decreases smoothly upon further addition of $\mathrm{CT} \Lambda \mathrm{B}$. The rate enhancement upon the addition of $\mathrm{CT} \Lambda \mathrm{B}$ is most significant for the reaction with $\mathrm{O}_{2} \mathrm{CC}_{6} \mathrm{IL}_{4} \mathrm{O}$ and least significant for the one with $\left.\mathrm{C}_{6}\right] \mathrm{I}_{5} \mathrm{O}$, indicating that the reactivity of these aryloxides in the presence of $C T \Lambda \mathrm{B}$ cannot be determined by the basicity alone. The strength of the interaction of these anionic aryloxides with the positively charged micellar aggregates has been suggested to be an important factor to determine the reactivity in the presence of CTAB. The $k_{c b s}$ value for the reaction with $\mathrm{Ox}$ increases also upon the addition of CTAB. Ilowever, the increase in the $k_{0 \mathrm{lls}}$ value is much more significant for the reaction with $\mathrm{Ox}$ than for the one with $\mathrm{ClC}_{6} \mathrm{H}_{4} \mathrm{O}$, indicating that $\mathrm{Ox}$ is less strongly solvated than $\mathrm{ClC}_{6} \mathrm{H}_{4} \mathrm{O}$ in $\mathrm{I}_{2} \mathrm{O}$. The $\alpha$-effect shown by $\mathrm{Ox}$ in $\mathrm{H}_{2} \mathrm{O}$ has been attributed to the ground-state solvation difference between $\mathrm{Ox}$ and $\mathrm{ClC}_{6} \mathrm{H}_{4} \mathrm{O}$.
\end{abstract}

Key Words : The $\alpha$-effect, Micellar effect, Basicity, Nucleophilicity, Bronsted equation

\section{Introduction}

Abnormally enhanced nucleophilic reactivity has often been reported for reactions with a certain type of nucleophiles. ${ }^{1,2}$ A common feature of these nucleophiles is the possession of one or more nonbonding electron pairs on the atom at the $\alpha$-position from the nucleophilic atom. Therefore, the term $\alpha$-effect was given to the enhanced nucleophilic reactivity of these nucleophiles compared with an isobasic reference nucleophile. ${ }^{1.2}$ The nucleophiles exhibiting the $\alpha$-effect are oximates $\left(\mathrm{R}_{2} \mathrm{C}=\mathrm{NO}^{-}\right)$, hydroxamates $\left(\mathrm{RC}(\mathrm{O}) \mathrm{NHO}^{-}\right.$), peroxide anions $\left(\mathrm{ROO}^{-}\right)$, hydrazines ( $\mathrm{RNH}-$ $\left.\mathrm{NH}_{2}\right)$, hydoxylamine $\left(\mathrm{HONH}_{2}\right)$, etc. ${ }^{1.2}$ Numerous studies have been performed to investigate the cause of the $\alpha$-effect. ${ }^{2 \cdot 4}$ Some suggested origins of the $\alpha$-effect are destabilization of the ground-state, stabilization of the transition-state and the reaction product, and solvent effect. ${ }^{2.9}$

We have performed systematic studies to investigate the effect of medium on the $\alpha$-effect for the nucleophilic substitution reaction of $p$-nitrophenyl acetate ( $\mathrm{PNI}$ 'A) with butane-2,3-dione monoximate $\left(\mathrm{Ox}^{-}\right)$and with $p$-chlorophenoxide $\left(\mathrm{ClC}_{6} \mathrm{H}_{4} \mathrm{O}^{-}\right)$as an $\alpha$-nucleophile and a corresponding normal-nucleophile, respectively, in dimethylsulfoxide (DMSO)- $\mathrm{H}_{2} \mathrm{O}$ mixtures of varying compositions.? The magnitude of the $\alpha$-effect $\left(k^{(\mathrm{O})} / k^{\left(\mathrm{Cl}_{6} \mathrm{H}_{4} \mathrm{O}\right)}\right.$ ) has been found to

This paper is dedicated to Professor Sang Chul Shim for his distinguished achievement in organic photochemistry and his outstanding contributions to the chemistry community in Korea. increase with increasing the DMSO content up to near 50 mole \% DMSO followed by a gradual decrease upon further addition of DMSO to the reaction medium, resulting in a bell-shaped $\alpha$-effect prophile. ${ }^{7}$ However, the correpnding reaction run in $\mathrm{CH}_{3} \mathrm{CN}-\mathrm{H}_{2} \mathrm{O}$ mixtures has shown an increasing $\alpha$-effect prophile as the $\mathrm{CH}_{3} \mathrm{CN}$ content in the medium increases." "The effect of medium on the $\alpha$-effect has also been investigated for the reaction of PNPA with $\mathrm{Ox}^{-}$and $\mathrm{ClC}_{6} \mathrm{H}_{4} \mathrm{O}^{-}$in the presence of a cationic surfactant, cetyltrimethyl ammonium bromide (ClAB). We have found that the reactivity of these nucleophiles increases with increasing the concentration of $\mathrm{C}$ IAB in the reaction medium up to $c a$. $4 \times 10^{-3} \mathrm{M}$. However, the $\alpha$-nucleophile $\mathrm{Ox}^{-}$has exhibited much larger rate enhancement than the normal nucleophile $\mathrm{ClC}_{6} \mathrm{H}_{4} \mathrm{O}^{-}$upon the addition of C TAB.

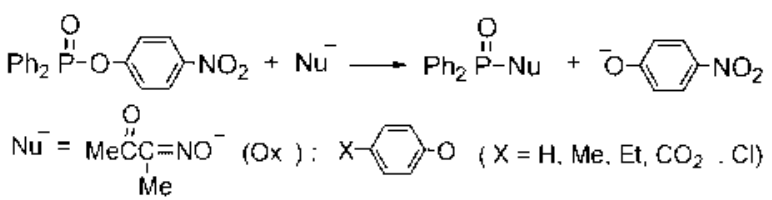

In order to obtain further information, we have extended our sutdy to the reaction of $p$-nitrophenyl diphenyl phosphinate (PNI'DPP) with $\mathrm{Ox}^{-}$and a series of $\mathrm{X}$-substituted phenoxides including $\mathrm{C}_{\mathrm{C}} \mathrm{C}_{6} \mathrm{H}_{4} \mathrm{O}^{-}$in the presence and absence of ClAB, eq (1).

\section{Experimental Section}

Materials, $p$-Nitrophenyl diphenyl phosphinate (PNPDPP) was easily prepared from the reaction of diphenyl phos- 
phiny l chloride with $p$-niltophenol in the presence of trichy lamine as a cataly st in dry ether. The phenols butane2.3-dione monoxime and $\mathrm{CTAB}$ were recry stalized before use. Other chemicals used were of the highest quality a ailable from Aldrich. Doubly glass distilled water was boiled and cooled under nitrogen.

Kinetics. The kinetic sludy was performed with a Scinco S-2100 Photodiode Array UV- $\mathrm{x}$ is spectrophotometer for slow reactions $\left(t_{1} \geq 10\right)$ s) or with an Applied Pholophysics SX-17 MV stopped-flow spectropholometer for fast reactions $\left(1_{1:}<10\right.$ s) cquipped with a Leslab RTE-1 l0 constant temperature circulating bath to keep the temperature in the reaction cell at $25.0 \pm 0.1{ }^{\circ} \mathrm{C}$. The reaction was followed by monitoring the appearance of the leaving $p$-nitrophenoxide at $400 \mathrm{~nm}$. Pscudo-first-order rate constants $\left(k_{0 \text { bss }}\right)$ were detcrmined from the well-known equation. $\ln \left(A \cdots-A_{\mathrm{t}}\right)=$ $-k_{v b \text { s: }} \cdot 1+c$. The concentration of the reactants was diluted to $1.0 \times 10^{-5} \mathrm{M}$ and $2.00 \times 10^{-4} \mathrm{M}$ for the substrate and the anionic nuclcophiles. respectively in order to minimize perturbation of micellar structures. All the solutions werc prepared just before use under nilrogen and were transferred by Hamilton gas-tight syringes. Other detailed kinetic procedures were reproted previously. ${ }^{7.8}$

\section{Results and Discussion}

Pscudo-first-order rate constants $\left(k_{\text {ols }}\right)$ arc summarized in Table $\mathrm{I}$ for the nuclcophilic substitution reactions of PNPDPP with a series of substituted phenoxides $\left(\mathrm{XC}_{6} \mathrm{H}_{4} \mathrm{O}^{-}\right)$ and butanc-2.3-dione monoximatc $\left(\mathrm{Ox}^{-}\right)$in $0.1 \mathrm{M}$ borate buffer solution $(\mathrm{pH}=10,0)$. As shown in Table l. the $k_{\text {abs }}$ value is similar for all the reactions with the ary loxides in the absence of CTAB. However the reactivity of the ary loxides is strongly dependent on the nature of the sustituent $X$ in the presence of CTAB. The eflect of CTAB on the $k_{\text {obs }}$ value is illustrated in Figure 1. It is shown that the $k_{\text {clts }}$ value for the reaction with the ary loxides increases sharply with increasing the concentration of $\mathrm{CTAB}$ in the reaction medium up to ca. $7 \times 10^{-4} \mathrm{M}$ and then decreases smoothly upon lurther addition of CTAB.

Significant rate cnhancements have olten been observed for nucleophilic substitution reaction with anionic nuclcophiles upon addition of various cationic surlactants. ${ }^{10-13}$ Iglesias has recently shown that the $k_{\text {obs }}$ valuc for hydrolysis of ethyl cyclohexanone-2-carboxylate passes through a maximum with increasing surlactant concentration followed by a gradual but steady decrease in the rate as the surfactant concentration increases lurther. ${ }^{11}$ Similarly. Toullec ${ }^{22}$ and Moss et $\mathrm{Cl}^{13}$ have found that the decontamination of toxic phosphonates and phosphates (e.g. pesticides or chemical warlare agents) are highly cllective in aqueous micellar solution. Such a rate cnhancement in aqueous micellar solutions has becn attributed to an increase in the concentration of reactants at the interface of micellar aggregates but not to an increase in the intrinsic reactivity. ${ }^{(0-1)}$ In fact. the secondorder rate constants have often becn lound to be smaller at the micellar interlace than the one measured in water. ${ }^{10-1.3}$

The ionic interaction between the positive micellar aggregates and the anionic nucleophiles is considered to be an important factor which inlluences the concentration of the reactants at the interlace of micellar aggregates. As shown in Figure l. the rate cnhancement upon the addition of CTAB to the reaction medium is most significant for the reaction with $-\mathrm{O}_{2} \mathrm{CC}_{6} \mathrm{H}_{4} \mathrm{O}^{-}$. Thereforc. one can suggest that ${ }^{-} \mathrm{O}_{2} \mathrm{C}$ $\mathrm{C}_{6} \mathrm{H}_{4} \mathrm{O}^{-}$cxerts the strongest ionic interaction with the positive micellar aggregates among the anionic aryloxides. This argument can be casily acceptable since there are two negative charges on ${ }^{-} \mathrm{O}_{2} \mathrm{CC}_{6} \mathrm{H}_{4} \mathrm{O}^{-}$. It is also shown that $\mathrm{ClC}_{6} \mathrm{H}_{4} \mathrm{O}^{-}$is more reactive than $\mathrm{C}_{6} \mathrm{H}_{5} \mathrm{O}^{-}$in the presence of CTAB, although the former is less basic than the latter. indicating that $\mathrm{ClC}_{6} \mathrm{H}_{4} \mathrm{O}^{-}$exerts a stronger interaction with the micelles of CTAB than $\mathrm{C}_{6} \mathrm{H}_{5} \mathrm{O}^{-}$docs. Therefore. one can suggest that the reactivity of these anionic nucleophiles cannot be determined by the basicity alone in the presence of CTAB. This argument can be further supported by the fact that the $k_{0 h}$ value at $7 \times 10^{-4} \mathrm{M} \mathrm{CTAB}$. in which the

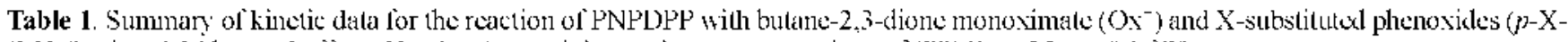
$\mathrm{C} 1 \mathrm{l}, \mathrm{O})$ in $0.1 \mathrm{M}$ borate buffor $(\mathrm{pll}=10.0)$ containing various concentrations of $\mathrm{C}$ " [ABr at $25.0 \pm 0.1 \mathrm{C}^{\prime \prime}$

\begin{tabular}{|c|c|c|c|c|c|c|c|}
\hline \multirow{2}{*}[\mathrm{C}\cdot\mathrm{CAB}\mathrm{r}]{$\times 10^{1} . \mathrm{M}$} & \multicolumn{7}{|c|}{$k_{0,1)} \times 10^{2}, s^{-1}$} \\
\hline & buller & $\mathrm{X}=\mathrm{Ox}$ & $X=C .1$ & $\mathrm{X}=\mathrm{CO}_{2}$ & $X=I I$ & $\mathrm{X}=\mathrm{CH}_{3}$ & $X=C_{2} I I$ \\
\hline 0 & 0.450 & 0.562 & 0.483 & 0.483 & 0.485 & 0.485 & 0.490 \\
\hline 1 & 0.483 & 1.90 & 0.640 & 0.550 & 0.500 & 0.533 & 0.683 \\
\hline 2 & 0.967 & 6.42 & 5.42 & 7.67 & 1.32 & 1.97 & 4.48 \\
\hline 3 & 3.28 & 27.0 & 8.52 & 12.9 & 5.27 & 7.17 & 8.87 \\
\hline 4 & 5.17 & 558 & 10.2 & 15.6 & 7.42 & 9.55 & 12.0 \\
\hline 5 & 6.42 & 76.9 & 10.9 & 17.1 & 8.52 & 10.9 & 13.6 \\
\hline 6 & 6.48 & 88.0 & 11.1 & 17.7 & 8.93 & 12.1 & 13.9 \\
\hline 7 & 6.55 & 94.4 & 11.3 & 19.3 & 9.32 & 12.5 & 14.4 \\
\hline 10 & 7.23 & 101 & 11.2 & 19.0 & 9.45 & 120 & 13.6 \\
\hline 16 & 6.87 & 98.0 & 9.60 & 17.6 & 9.03 & 11.4 & 12.0 \\
\hline 28 & 6.17 & 82.7 & 7.97 & 15.1 & 7.95 & 9.18 & 9.55 \\
\hline 40 & 5.72 & 70.8 & 7.13 & 11.7 & 7.48 & 8.15 & 8.18 \\
\hline
\end{tabular}

"[PNPDPP $]-1.0 \times 10^{-5} \mathrm{M},\left[\mathrm{Nu}^{-}\right]-2.00 \times 10^{-1} \mathrm{M}$, where $\mathrm{Nu}^{-}-\mathrm{Ox}^{-}$or $\mathrm{XC}_{6} \mathrm{H}_{+} \mathrm{O}^{-}$ 


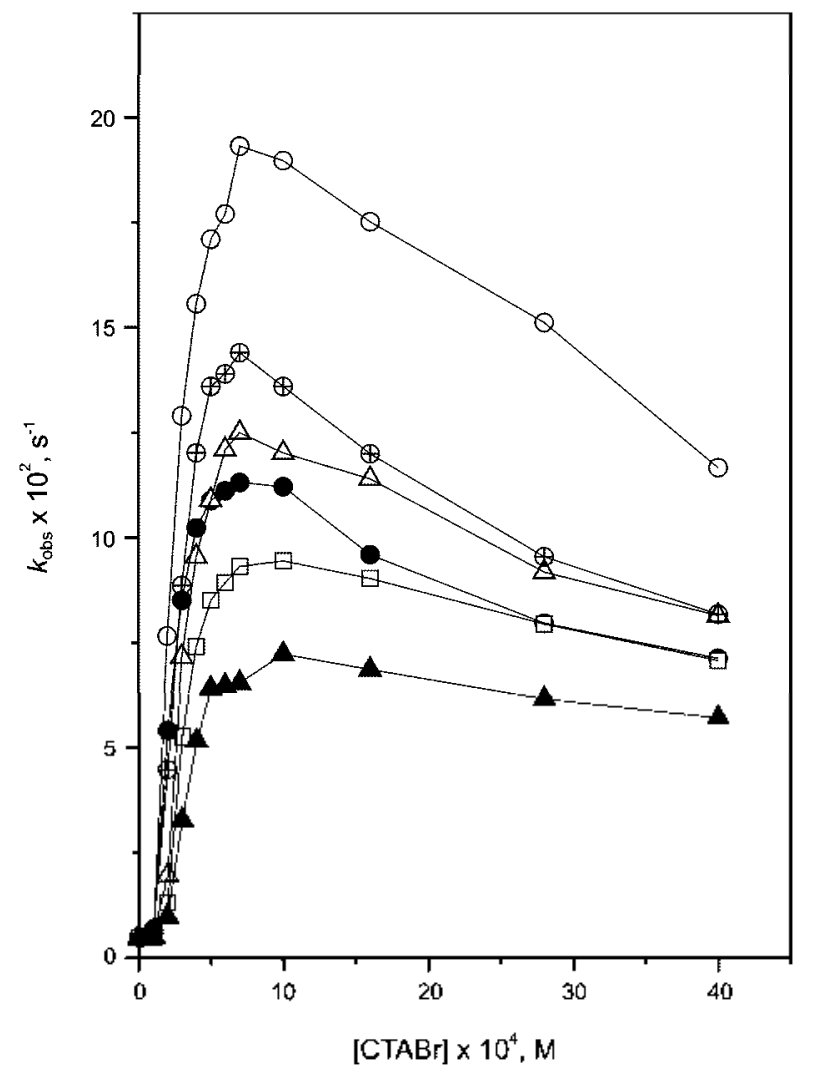

Figure 1. Plols of observed rate constants is concentration of CTAB for the reaction of PNPDPP with substituted phenoxides $(p-$ $\left.\mathrm{X}-\mathrm{C}_{0} \mathrm{H}_{1} \mathrm{O}^{-}\right)$in $0.1 \mathrm{M}$ botate buffer $(\mathrm{p} \mathrm{H}=10.0)$ at $25.0 \pm 0.1{ }^{\circ} \mathrm{C} .(\mathrm{X}=$

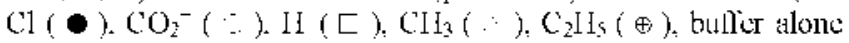
$(\boldsymbol{A})$.

maximum $k_{\text {cles }}$ value is observed. is in the order $\mathrm{C}_{6} \mathrm{H}_{5} \mathrm{O}^{-}<$ $\mathrm{MeC}_{6} \mathrm{H}_{3} \mathrm{O}^{-}<\mathrm{E}_{1} \mathrm{C}_{6} \mathrm{H}_{4} \mathrm{O}^{-}$although the basicity of these ary loxides is similar each other (Sce Table $\mathrm{l}$ and Figure l).

It has been reported that the association constant $\left(K_{\text {ass }}\right)$ between the micelle of $\mathrm{CTAB}$ and the aryloxides is in the order $\mathrm{EtC}_{6} \mathrm{H}_{4} \mathrm{O}^{-}>\mathrm{MeC}_{6} \mathrm{H}_{4} \mathrm{O}^{-}>\mathrm{C}_{6} \mathrm{H}_{5} \mathrm{O}^{-}{ }^{14}$ which is the same as the $h_{0}$ ws value for the reaction of PNPDPP with the three aryloxides. Therefore. one can suggest that the reactivity of these anionic nucleophiles would be governed by two factors as shown in eq (2), where $a$ and $b$ represent the sensitivity parameter for $K_{\mathrm{ass}}$ and $K_{\mathrm{b}}$ (= basicity of ary loxides). respectively. Eq (2) would resemble the Bronsted equation when the first term of eq (2) becomes zero. On the other hand. the reactivity of nucleophiles would be determined by the strength of the interaction between the micelle and the anionic nucleophile when the basicity of the mucleophiles is similar.

$$
\log k_{\mathrm{obs}}=\mathrm{a} \log K_{\mathrm{ass}}+\mathrm{b} \log K_{\mathrm{b}}
$$

Some years ago. we performed nucleophilic substitution reactions of $p$-nitrophenyl acetate (PNPA) with a series of aryloxides in the presence of CTAB. The $k_{\text {olls }}$ value was found to increase with increasing the concentration of $\mathrm{CTAB}$ up to $c a .4 \times 10^{-3} \mathrm{M}$ and then remained nearly constant upon further addition of CTAB to the medium. ${ }^{9}$ However the rate

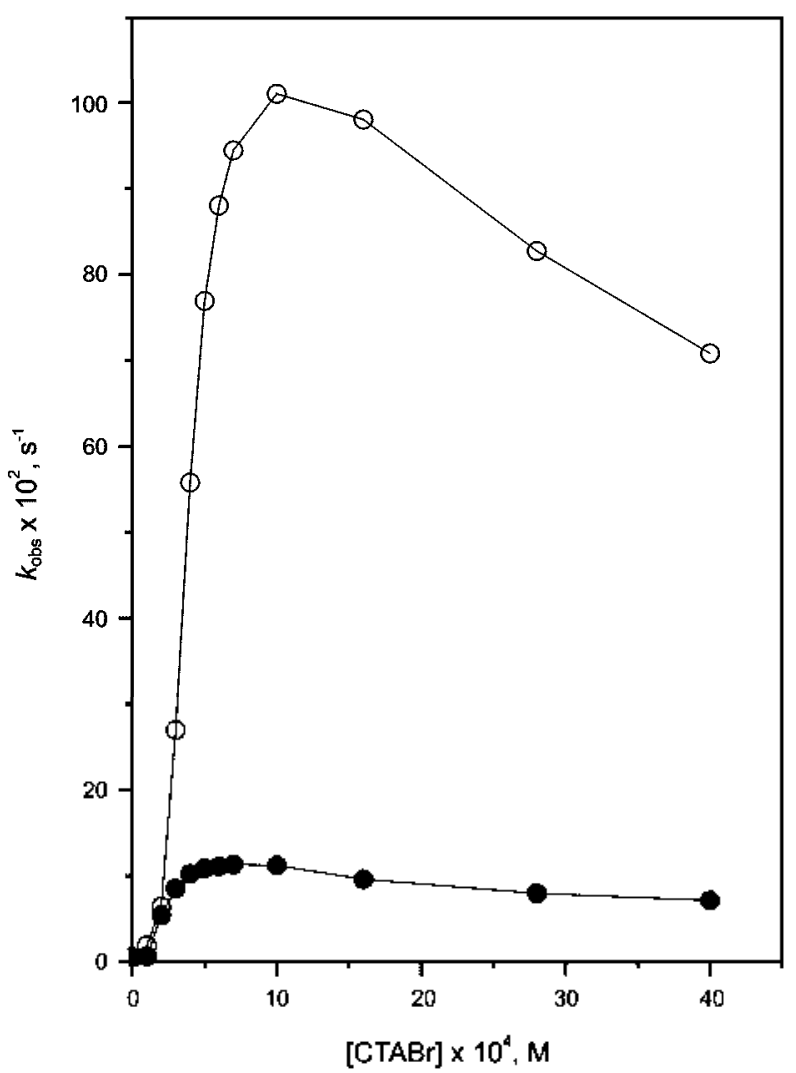

Figure 2. Plots of observed rate constants vs concentration of CTAB for the reaction of PNPDPP with $p$-chlorophenoxide ( ) and bulane-2,3-dione monoximate (: :) in $0.1 \mathrm{M}$ borale buller (pll $=10.0)$ a $25.0 \pm 0.11^{\circ} \mathrm{C}$.

cnhancement upon addition of CTAB for the reaction of PNPA was calculated to be only about 10. which is much smaller than the corresponding rate cnhancement for the reaction of PNPDPP under the same reaction condition (e.g. the rate cnhancement of about 20-40. sce Table 1). Thus. one can suggest that the effect of micelle on rate is also depenldent of the nature of the substrate for given nucleophiles. The difference in the hydrophobicity between PNPDPP and PNPA is considered to be responsible for the difference in the micellar effect on rate and the position of the maximum $k_{\text {olls }}$ value appeared (e.g.. PNPDPP being nore hy drophobic than PNPA).

Table 1 shows that $\mathrm{Ox}^{-}$is more reactive than $\mathrm{ClC}_{6} \mathrm{H}_{4} \mathrm{O}^{-}$in the presence and absence of $\mathrm{CTAB}$ although the basicity of $\mathrm{Ox}^{-}$and $\mathrm{ClC}_{6} \mathrm{H}_{\downarrow} \mathrm{O}^{-}$is similar each other. The $\alpha$-effect nucleophile $\left(\mathrm{Ox}^{-}\right)$has often exhibited higher reactivity than the corresponding normal nucleophile $\left(\mathrm{ClC}_{6} \mathrm{H}_{4} \mathrm{O}^{-}\right)$toward a variety of substrates (e.g. the $\alpha$-effect) ${ }^{7.8}$ We have recently performed nucleophilic substitution reactions of $S$-p-nitrophenyl thioactate (PNPTA) with $\mathrm{Ox}^{-}$and $\mathrm{ClC}_{6} \mathrm{H}_{+} \mathrm{O}^{-}$in DMSO$\mathrm{H}_{2} \mathrm{O}$ mixtures of varying compositions. ${ }^{15}$ The nucleoplilic reactivity was found to increase significantly with increasing the concentration of DMSO in the reaction mediunn. However. the rate enhancement upon additions of DMSO was found to be more remarkable for the reaction with $\mathrm{Ox}^{-}$than for the one with $\mathrm{ClC}_{6} \mathrm{H}_{4} \mathrm{O}^{-}$up to ca. 50 mole \% DMSO. ${ }^{15}$ 
The difference in the ground-state solvation of $\mathrm{Ox}^{-}$and $\mathrm{ClC}_{6} \mathrm{H}_{4} \mathrm{O}^{-}$was suggested to be responsible for the differential medium effect on rate. ${ }^{15}$ A similar result has becn obserned for the reactions of PNPA ${ }^{7}$ PNPDPP and $p$ nitrophenyl ben/ensulfonate (PNPBS) ${ }^{16}$ under the same reaction condition. although the magnitude of the $\alpha$-effect was found to be dependent on the substrates.

Figure 2 illustrates the effect of CTAB on the reactivity of $\mathrm{Ox}^{-}$and $\mathrm{ClC}_{6} \mathrm{H}_{4} \mathrm{O}^{-}$toward PNPDPP. One can sec that the $k_{0}$ ex value increases upon addition of CTAB to the reaction medium up to $c a, 7-10 \times 10^{-4} \mathrm{M}$ CTAB. However the increase in the $k_{\text {bbs }}$ value is much more remarkable for the reaction with $\mathrm{Ox}^{-}$than with $\mathrm{ClC}_{6} \mathrm{H}_{4} \mathrm{O}^{-}$. Since the basicity of the two nucleophiles is similar each other. ${ }^{7}$ the differential micellar effect would be mainly due to the difference in the interaction between the micelle and the nucleophile. The ionic interaction of the positive micelles with $\mathrm{Ox}^{-}$and with $\mathrm{ClC}_{6} \mathrm{H}_{4} \mathrm{O}^{-}$would be similar since both of the nucleophiles have a negative charge. Thereforc. a difference in the ground-state solvation betwecn $\mathrm{Ox}^{-}$and $\mathrm{ClC}_{6} \mathrm{H}_{4} \mathrm{O}^{-}$would be responsible for the differential micellar effect on rate shown in Figure 2. The fact that the rate enhancement upon the addition of CTAB is more significant for the reaction with $\mathrm{Ox}^{-}$indicates that $\mathrm{Ox}^{-}$is less strongly solvated than $\mathrm{ClC}_{6-}^{-}$ $\mathrm{H}_{4} \mathrm{O}^{-}$in $\mathrm{H}_{2} \mathrm{O}$. This argument is consistent with our recent calorimetric study. i.e. $\mathrm{Ox}^{-}$is aboul $4 \mathrm{kcal} / \mathrm{mole}$ less solvaled than $\mathrm{ClC}_{6} \mathrm{H}_{4} \mathrm{O}^{-}$in $\mathrm{H}_{2} \mathrm{O}$ at $25.0^{\circ} \mathrm{C}^{7 \mathrm{t}}$ Therelore. the present result suggests that differential ground-state solvation $\left(\mathrm{Ox}^{-}\right.$ w $\mathrm{ClC}_{6} \mathrm{H}_{4} \mathrm{O}^{-}$) is responsible for the cnlanced nuclcophilic reactivity of $\mathrm{Ox}^{-}$in the reaction with various sbustrates.

\section{Conclusion}

The $k_{\text {cos }}$ value for the reaction of PNPDPP with $\mathrm{XC}_{6} \mathrm{H}_{4} \mathrm{O}^{-}$ and $\mathrm{Ox}^{-}$increases sharply with increasing the concentration of $\mathrm{CTAB}$ in the reaction medium up to $\mathrm{ca} .7 \times 10^{-1} \mathrm{M}$ and then decreases gradually upon furlher addition of CTAB. The fact that micellar effect on rate is much more significant for the reaction with $\mathrm{Ox}^{-}$than for the one with $\mathrm{ClC}_{6} \mathrm{H}_{7} \mathrm{O}^{-}$ suggests that $\mathrm{Ox}^{-}$is less strongly solvated than $\mathrm{ClC}_{6} \mathrm{H}_{4} \mathrm{O}^{-}$in
$\mathrm{H}_{2} \mathrm{O}$. Therefore the $\alpha$-effect shown by $\mathrm{Ox}^{-}$in $\mathrm{H}_{2} \mathrm{O}$ is attributed to the ground-state solvation dillerence between $\mathrm{Ox}^{-}$and $\mathrm{ClC}_{6} \mathrm{H}_{4} \mathrm{O}^{-}$in $\mathrm{H}_{2} \mathrm{O}$.

Acknowledgment. The authors arc gratclul for the financial support from KISTEP (MI002204(00)(04-0) G0509()0710).

\section{References}

1. Edwards. J. O.: Pearson. R. G. J. Lh. Chem. Soc, 1962. 84. 16.

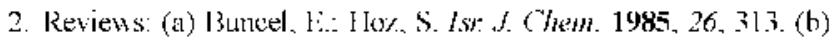
lina. N. I.: lidward. I. O. ht. J. (hem. Kinet 1973. 5. 1. (c) Grekon. A. P:: Veselor. V. Y, Lsp. Khim. 1978. +7. $12(0)$

3. (a) Moutiers. G.: Guevel. E. L.: Vilien. L.: Terrier. F. J. (hem. Sex. Pestin Trows. 2 1997. 7. (b) Terrier. F.: Moutiers. G.: Xiao. L.: Guir I. J. Org Chem 1995, 60, 1748.

4. (a) lountain. K. R.: Tad-y. 1) B.: Paul, 1. W. (jolynskiy, M. V.J. Org. (Thm. 1999.6t.6547. (b) Fountain. K. R.: I)unkin. T. W: Patcl. K. D. J. Org. (Tkm. 1997. 62.3711. (c) Fountain. K. R.: Patcl. K. D. J. Org ( $\%$ men. 1997.62.4795.

5. (a) Herschlag. D.: Icneks. W. P. J. th. Chem. Soc, 1990. 112. 1951. (b) Ilerschlag. 1). Jencks. W. P. J . L Chem. Soc. 1989. III. 7579). (c) Palling I) . . Jencks. W. P. J. Im (Them. Soc. 1984. 106. 4869 .

6. (a) Bernasconi. C. F.: Murray. C. T. J. Am. Chem. Soc. 1986. 108. 5251. (b) Dixon. I. E.: Bruice. T. C. $J . t m$. C $7 \mathrm{~km}$. Soc 1972. 94. 2052 .

7. (a) ] Buncel. I... Um. I. II. J. Chem Soc Chen Conmm 1986. 595. (b) Um. I. I I.: 13uncel. I. J. Org. (hem. 2000. 65. 577.

8. (a) Um. I. II. I ee I I. I. Buncel I. J. O . . Chem. 2001, 66, 4859. (b) Um. I. H.: Park. Y. M.: Buncel. E. Chem. Commm. 2000. 1917.

9. Un. I. H. Bull Konew (hon. Soc, 1990. H. 173.

10. Iiendler. I. II: Fendler. I. I. Catalssis in Hatellor and Nacromoleculo Sustens, Academic Press: New York. 1975.

11. Iglasias, F. J. Phys. Chem. B 2001. 105. 10287.

12. Toullec. J.: Moukawim. M. Chm. Commm. 1996. 221.

13. Moss. R. A.: Kotchevar. A. T.: Park. B. D.: Scrimin. P. Lamgmar 1996. 12. 2200 .

14. (a) Um. I. I I. I Le S. I... Jung. I. K.: Park. J. Y. Bull. Sow Chem Soc. 1992, 13, 486. (b) Bunton. C. A.: Sepulveda. I.. .J. Phus. (7tem 1979, 83.680 .

15. Unl. I. H.: Buncel. E. J.Am. Chm. Soc. 2001. 123.11111.

16. Unl. I. H.: Hong. J. Y.: Buncel. E. C/km Comman. 2001. 27. 